\title{
Spatiotemporal Changes of Vegetation in the Middle Draa Valley Oasis: A Study Case of M'hamid El Ghizlane Oasis (Morocco)
}

\begin{abstract}
Atman Ait Lamqadem, Hafid Saber, Abdelmejid Rahimi,

Laboratory of Geodynamic and Geomatic, Department of Geology, Faculty of Sciences, Chouaïb Doukkali University, El Jadida, Morocco

doi: 10.19044/esj.2017.v13n24p115 URL:http://dx.doi.org/10.19044/esj.2017.v13n24p115

Abstract

During the last decades, The Middle Draa Valley (Southeast of Morocco) was subjected to various environmental problems which haves caused land degradation especially in the south of the Middle Draa (M'hamid oasis). This study aims to analyze the spatiotemporal changes of vegetation in the M'hamid oasis. Based on the Landsat images belonging to six separate periods during 1984 to 2016 and Geographical Information System (GIS) techniques, the pattern of spatiotemporal changes of vegetation cover in M'hamid oasis was analyzed based to visual interpretation and NDVI (Normalized Difference Vegetation Index) and supervised classified. For easier understanding of the causes and origins of these changes, we exploited statistical data survey from various local administrations (climatological, socio-economic data) and fieldworks. The results show that the total area of the oasis showed an oscillating decrease between 1984-1999 compared to 1999-2013 and a sharp increase after 2003 to 2007 and a moderate decrease from 2003 to 2016, with an area 3 times smaller than the initial date (loss of $22 \%$ of oasis area), correlated with a reduction of the habitants (loss of 21\% between 1980 and 2016). Mass tourism, construction of the Mansour Eddahbi dam and the irregularities of the rains and the succession of years of drought led to a modification of the oasis ecosystem. Due to these climatic conditions, the oasis population are obliged to emigration thus they leave their fields which are threatened by sand encroachments, therefore accelerating the phenomenon of sand movements and consequently desertification.
\end{abstract}

Keywords: Landsat images, NDVI, GIS, Spatiotemporal changes, M'hamid El Ghizlane oasis 


\section{Introduction}

An oasis is an isolated green fertile land in a desert that often surrounds a water source such as a spring; it provides habitat for animals, and sometimes humans (Xie et al., 2015). The main landscapes of oases in Morocco are vegetation especially palm trees, rivers and settlements. Although oases present $15 \%$ of the area of Morocco (Karmaoui et al., 2015). The majority of these oases are located in the southeastern part of Morocco and knew a rapid transformation of landscapes during the last years, caused principally by sand dunes encroachments and desertification (Benmohammadi et al., 2000).

The arid land is distinguished by its fragility and it is characterized by several environmental problems such as water shortage, soil degradation, and low rainfall (Kassan, 1977). The majority of arid and Saharan Moroccan lands is located in the south and southeast, where the Middle Draa Valley belongs. This last is the subject of multiple environmental studies in recent years, but few studies analyzed the environmental dynamic in this region using remote sensing data and GIS techniques. Most of the studies have analyzed the environmental changes in the Middle Draa Valley by integrating various thematic aspects, such as the study of relationships between environmental ruptures and migratory actions (Aït Hamza \& El Faskaoui, 2010), and the relationship between tourism and the degradation of oases (Martin, 2006; Sobczak, 2008). On the other hand, other researchers focused on the phenomenon of silting and desertification (Benmohmmadi et al., 2000; Bentaleb, 2008). However, few studies have explored spatial tools and satellite images in the monitoring of the spatiotemporal dynamics in this arid area, among which we cite the example of long term vegetation change detection using Landsat data from 1974 to 1999 (Schmidt, 2003) and monitoring of the land cover of oasis of Zagora through satellite images between 1984 and 2015 (Bouazzaoui et al., 2016).

Internationally, many studies have used multi-sources and multisensor satellite images in spatiotemporal changes of oases (G. M. Afrasinei et al., 2017a; Gabriela M Afrasinei et al., 2017b), especially in China. For example, the spatio-temporal processes of oasis development in the central part of the Heihe River Basin have been studied using moderate-resolution imaging spectrometer Normalized Difference Vegetation Index data (Tian et al., 2013) from 2000 to 2009, whereas the spatiotemporal changes in oases in the same basin, were studied between 1963 to 2013 employing satellite images and statistical data for reconstitution of the oases using NDVI, and temporal and spatial models, and evaluating the sensitivity of ecosystems to soil salinization in the Manas River Basin using Landsat Oli images (Zhang et al., 2017).while, other studies integrate the driving forces of spatiotemporal changes (Xie xue et al., 2016; Amuti \& Luo, 2014). 
In this paper, we focus on the "reconstruction" of the evolution of the M'hamid oasis from 1984 to 2016 using 7 periods of multi-temporal and multi-sensors of the Landsat satellite program. The particularity of this study is the first detailed study of analyzing land degradation in the M'hamid based on remote sensing data and GIS techniques. The M'hamid oasis which is the last oasis in the Middle Draa Valley, is the most threatened one by environmental risks (desertification, sand movements, scarcity of water). We extracted the vegetation of the oasis using spectral index (NDVI), analyzed the changes in oasis boundaries over the last three decades, and finally, we discussed the dynamics and contribution of different driving factors.

\section{Study area}

\section{Geographical setting}

Geographically, the Middle Draa Valley (MDV) is located in the southeastern part of Morocco, in the South of Atlas Mountains. It is located in the middle of the meridian $6^{\circ}$ West and below the thirtieth parallel North. The basin of Draa has an area of approximately $14380 \mathrm{~km}^{2}$ and a width of $1200 \mathrm{Km}$. The altitudes vary between $500 \mathrm{~m}$ and1000m. The bed of the Draa river forms a chain of six successive oases (Fig. 1), with less than $5 \mathrm{~km}$ in width (Mezguita, Tinzouline, Ternata, Fezouata, Ktaoua and M'hamid). Administratively, the Draa valley is a part of Zagora province, which includes 2 urban and 18 rural communities. Due to the arid climatic conditions, rainfall varies between $108 \mathrm{~mm}$ upstream of the valley (Agdez) and $54 \mathrm{~mm}$ downstream part (M'hamid), the evaporations are high and attains approximatively $3000 \mathrm{~mm} /$ year. The temperatures can reach more than $48^{\circ} \mathrm{C}$ in summer and between -1 and $7{ }^{\circ} \mathrm{C}$ in winter. The dominant winds in the region are Chergui, dry and hot, coming northeast, being more frequent in summer, and Sahili, freshly, coming from Southwest during winter (Bentaleb, 2008).

In this paper, we chose the M'hamid Oasis as a case study. It is located at the edge of Sahara, quite at the -Moroccans-Algerian border, and is threatened by environmental risks, such as drought, salinity, sand encroachments, and the Bayoud disease (Aït Hamza \& El Faskaoui, 2010). 


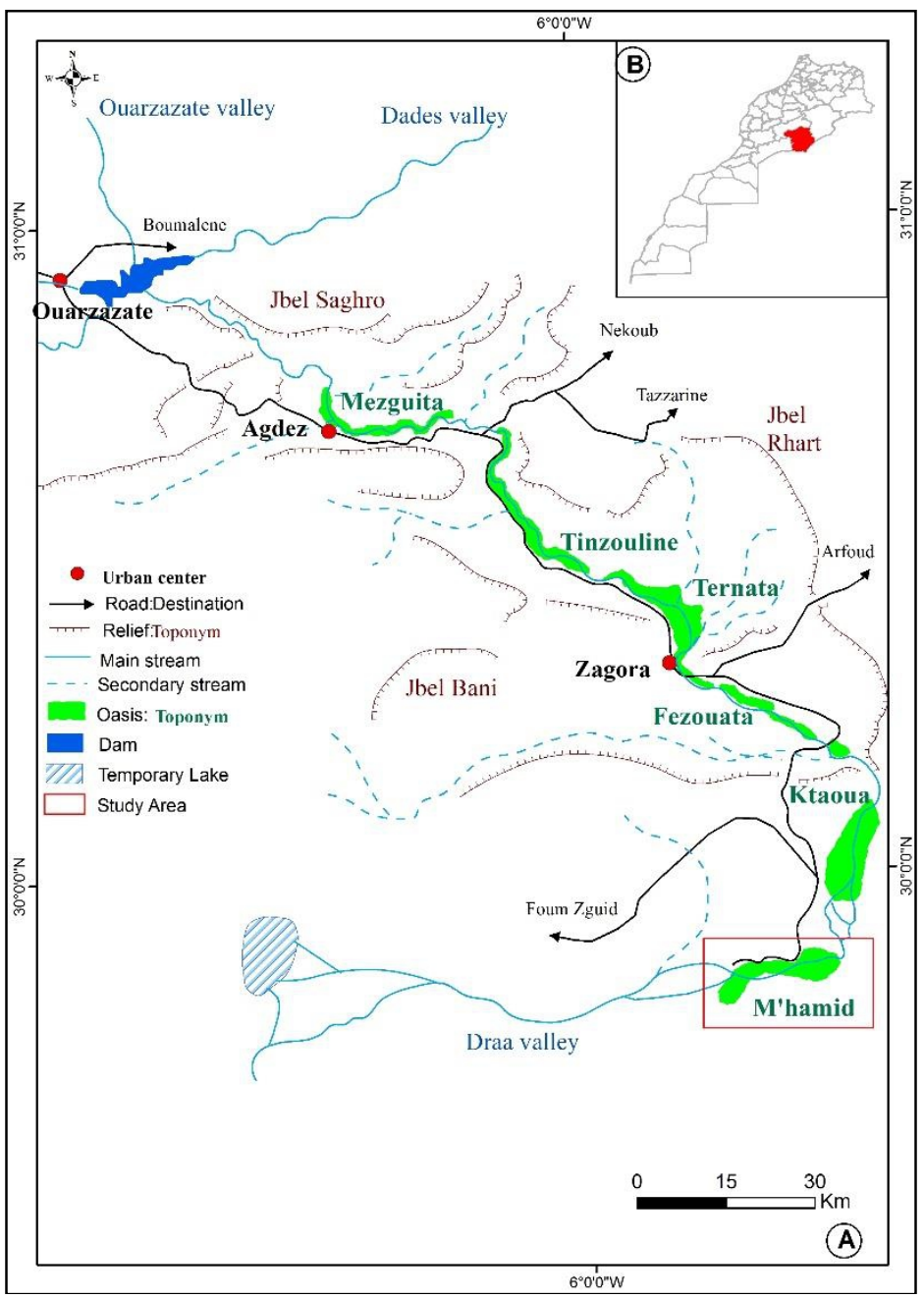

Fig. 1. A: Location of MDV. B: Location of MDV at national scale.

\section{Geological setting}

Geologically, the Middle Draa is a part of the Anti-Atlas domain (Lower Palaeozoic formation) and Bani (the Ordovician Mountain), whose geological formations belong to varied ages from the Precambrian to the Quaternary (Robert-Charrue, 2006). The Precambrian formations consist of: a volcanic and volcano-detritic deposits, while the Infra-Cambrian (Adoudounian): is represented by sedimentary deposits of a coverage made up a conglomerate, and sandstone associated with a casting of andesite overcome by volcanism of Alougoum, followed by lower limestones of the Aboudounien (Algouti et al., 2001). The Cambrian rocks are represented by Georgian calcareous schist (50-175m) and sandstone (green sandstone. The Ordovician series are represented by the lower and the upper schists of Fezouata, crowned by a sandstone level (schists of Trachilla) following by 
the quartzite of the first Bani and the sandstone of the second Bani and (Helg et al., 2004). The Silurian and Devonian correspond to the sandstone-schists series forming a bedrock of the last alluvial cuvette of M'hamid. The last stratigraphic unit is represented by the Quaternary, marked by sedimentary deposits coming from a fluvial erosion as well as from wind erosion. (Ouhajou, 1996).

\section{Data and method}

Data

To achieve the objectives, a large amount of data was used such as climatic data, including temperatures and rainfall as well as socio-economic surveys from 1984 to 2016 belonging to various local administrations. We also acquired remote images from the USGS Landsat archive, namely Landsat TM, ETM+, and OLI (WRS path 201, row 39) which were the primary data sources of our study. These images were obtained during 1984 to 2016 in seven steps $(1984,1988,1999,2003,2007,2013$ and 2016; see table 1).

Table 1. Landsat images description

\begin{tabular}{|c|c|c|}
\hline Year & Acquired date & Sensor \\
\hline 1984 & 27 August 1984 & TM \\
\hline 1988 & 05 July 19988 & TM \\
\hline 1999 & 12 July 1999 & ETM \\
\hline 2007 & 27 August 2007 & TM \\
\hline 2003 & 29 June 2003 & OLI \\
\hline 2013 & 27 August 2013 & OLI \\
\hline 2016 & 03 August 2016 & \\
\hline
\end{tabular}

The satellite images chosen are taken in summer, during harvest period of the seasonal agriculture, to avoid confusion between the permanent and seasonal vegetation.

These images were principally selected for their cloud-free scenes (cloud cover $=0$ ) acquired between June and September, when crops were collected for better assessment of the dynamics of palm tree oasis. This raw data needed processing and the deployment to explore it better.

\section{Method}

The methodological approach followed in this research is illustrated in figure 2. It is composed of three main components. The first concerns the preprocessing and the corrections of the proper radiometric anomalies to the sensor and the effects of the atmosphere, as well as geometrical corrections in order to superpose differences multi-date images, then the calculation of NDVI. The NDVI extracted is reclassified into two classes (vegetation, no vegetation) based to the ground truth and high-resolution images of google 
earth. The second component concerns the collection, processing and synthesis of the different statistical data (climatological, socio-economical) from different administrations and fieldwork, the aim of using these data is to find explications of spatiotemporal dynamics changes in the study area.

\section{Preprocessing of Landsat images}

In order to abotain refined results reflecting the ground-based measurments, we have proceeded to a radiometric calibration of the sensor and the atmoshperic corrections of our images. These operations were performed by combining them in a single step to preserve the radiometric integrity (Maimouni et al., 2011). The calibration of the sensor allows the conversion of Digital Number (DN) in visible luminance to correct to the anomalies to peculiar to the sensor and to exact reliable and precise information (Bannari et al., 1999). The calibration coefficients published in the metadata file were used for each image (NASA, 2012). Then, this apparent luminance was transformed into apparent reflectance by introducing solar illuminance, solar angle of incidence and distance and the distance "Sun-Earth" (Tanré, 1982). In the last, we convert the apparent reflectance to the reflectance of soil using the parameters of acquisition date, zenith solar zenith angle, atmospheric model, aerosol model and visibility of soil (Nicholas, 2017; Teillet \&Santer,1991; Bannari et al.,1999). In M'hamid, the oasis is characterized by vegetation. The vegetation can be easily extracted and distinguished from background using the developed spectral indices, in our case the NDVI was used (Liangliang, 2017).

\section{Vegetation extraction}

The main classes of land cover in oases of Morocco are the vegetation with palm tree and mountain or sand dunes, the extraction of vegetation is very easy using vegetation indices. The NDVI is used in many studies to detect vegetation changes in arid and semi-arid areas (Rahaman, 2017; Maimouni, 2011, Bannari et al., 1995). the NDVI is the most popular and the must use (Rouse et al., 1974), is calculated by the diffrence between the red $\mathrm{R}$ and the near infrared (NIR) bands divded by the sum of the red and near-infrared bands (Munkhasan, 2017), with the values vared between -1 (ice, water) and 1 (high density vegetation).

In the arid areas, the density of vegetation cover is very low, the vegetation starts generally from 0.13 of NDVI (Bouazzaoui et al., 2016). In this study, the threshold value is 0.13 , we based to the terrain truth, we carried out several GPS points of the limits between vegetation oasis and soil background (Xie et al., 2012). We processed also to visual interpretation with high resolution images of google earth for the recent years (since 2003), 
in order to refine the extraction of vegetation cover, and the interview with local resident and the consultation of different archives maps.

\section{Analysis of spatiotemporal changes of vegetation oasis}

The constant spatial changes in the oasis can be identified based on its changes area between the beginning and the final years (xie et al., 2015). This evolution characterized by the rate of changes and the changes patterns that oasis exhibit (Luo et al., 2008; Zhou et al., 2010, Tian et al., 2013). Land use and land cover models are widely used to analyze changes in oases (Luo et al., 2008; Zhou et al., 2010; Xie et al., 2014).

Several models were developed to analyze the time-oriented rate changes of oases such as change rate $\mathrm{Rd}$ that used to reflect the changes of total amount to different land cover types, the Single type trend degree Rs shows the change speed in amount of a certain LUCC type at a certain period of time in the region (Wang, 2011), the bidirectional dynamic degree model (BDD; Liu \& He 2002) and the Single Dynamic Degree Model (SDD; Liu et al., 2002).

In our study, the SDD model was used to assess the time-oriented rate changes in M'hamid oasis that describes the rate of the net change and neglects the increasing and decreasing components during the chosen period. The SDD (equation 1) is determined by the ratio of the difference area between two periods divided by the initial area (Liu \& He 2002;), it can be calculated as follows:

$$
\mathrm{SDD}=\frac{\mathrm{A}_{(\mathrm{T} 2)-} \mathrm{A}_{(\mathrm{T} 1)}}{\mathrm{A}_{(\mathrm{T} 1)} *(\mathrm{~T} 2-\mathrm{T} 1)} * 100 \quad(\text { Equation } 1)
$$

Where $\mathrm{A}$ is the total area of oasis and T1 and T2 are the beginning and the final years.

The pattern of space changes was analyzed using the change detection between the last date 2016 and the first date 1984. In change detection, there are two methods, the post classification approach which is the comparative analysis of independently produced classifications for different dates (Alagu et al., 2013) and the pixel-to-pixel approach (Nemmour and Chibani, 2004; Hussain et al., 2013) which is a simultaneous analysis of multispectral images. We used the pixel-to-pixel approach that is very useful in our case study (El-Hattab, 2016), we applied the change detection after the classification of NDVI into 2 classes. The result of this transformation is a map with three categories: "Unchanged", in this case no change in the boundaries is remarked, the second is "Expansion" presented by the area where the oasis was expensed, and the last is "Contraction", where the oasis is subjected to significant reduction. 


\section{Exploitation of external data}

In the second component, we have treated climatological data and average annual temperature, the annual precipitation average, groundwater salinity, information related to the economy and migration. The aim of the use of those data is to find the driving forces of spatiotemporal changes of vegetation oasis (population growth, climate condition, migration, tourism) and state policy towards oasis (palm replanting, sand dunes fixation).



Fig. 2. Methodological flowchart

\section{Results and discussions}

Results

The NDVI of M'hamid oasis

The NDVI was calculated after the preprocessing of Landsat images, and shows a critical decrease between 1984 and 2016 (Fig. 3).

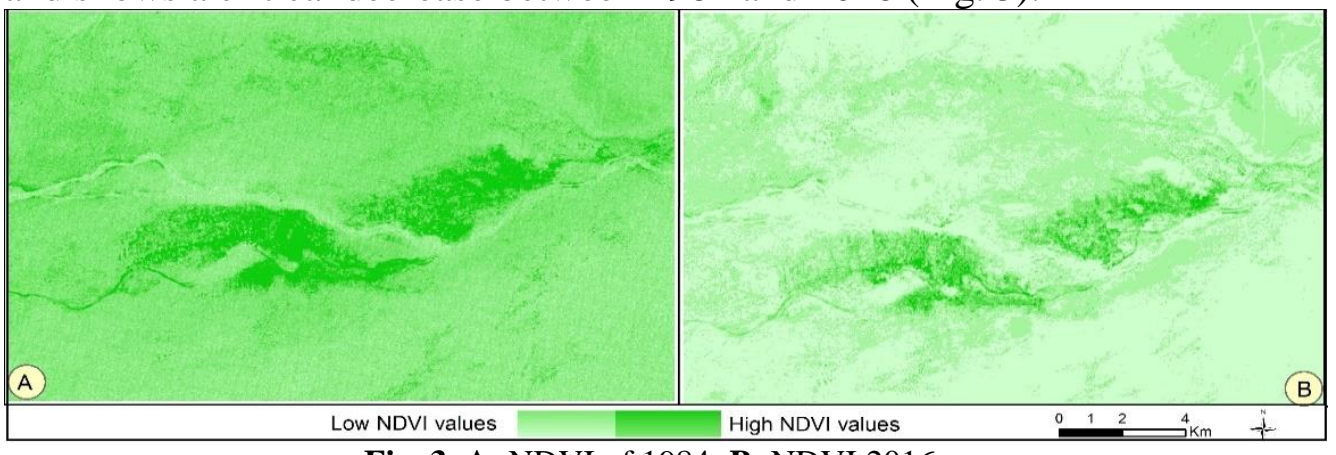

Fig. 3. A: NDVI of 1984; B: NDVI 2016 


\section{The time oriented change}

After the reclassification of the NDVI, the total area was calculated for each period of study from 1984 to 2016 that is divided into six periods. The measures of total oasis area shown in Figure 3, demonstrate a crucial decrease over the past 30 years, reaching a value of $11.86 \mathrm{~km}^{2}$ in 2016 , present the third of the initial area of $1984\left(37.5 \mathrm{~km}^{2}\right)$. The oasis area decreased significantly in the period 1984/1999, 1999/2003, with SDDs of $5.4,-30 \%$ respectively, and a remarkable increase in the period 2003/2007 followed by a stability in the period $2007 / 2013$, prior to the oasis continues its destruction to 2016 , with SDDs are $6.93,-0.01$ and $-2.5 \%$ respectively.

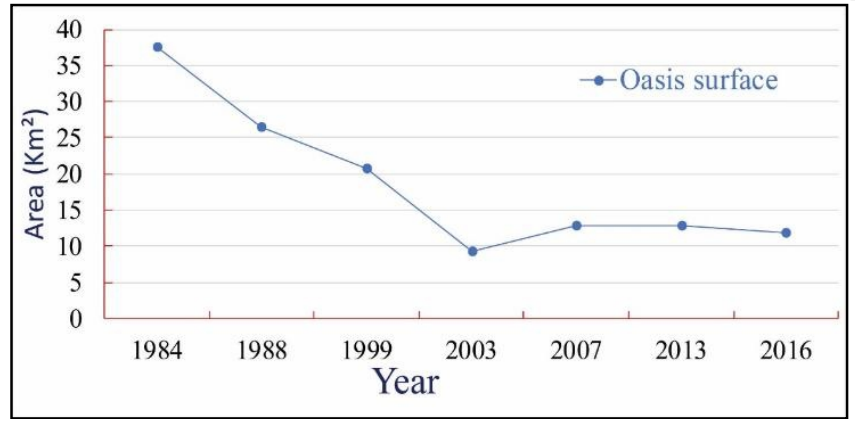

Fig. 4. Changes of vegetation area of the M'hamid oasis between 1984 and 2016

\section{The change detection of Vegetation oasis}

The result of the change detection using pixel-to-pixel approach from 1984 to 2016 indicates several changes, marked by a great extinction of a large part of the vegetation of M'hamid oasis (Fig. 5). The map obtained of the spatiotemporal changes in M'hamid oasis between 1984 and 2016, presents three classes, the first indicates the expansion zones (Expanding), presented in brown color, the second designates the resistant zones (Unchanged), represented in green color and located mainly in the center of the oasis, near of the residences (Ksours), while the magenta color represents the areas that the oasis lost (Decreasing) in the last three decades. 


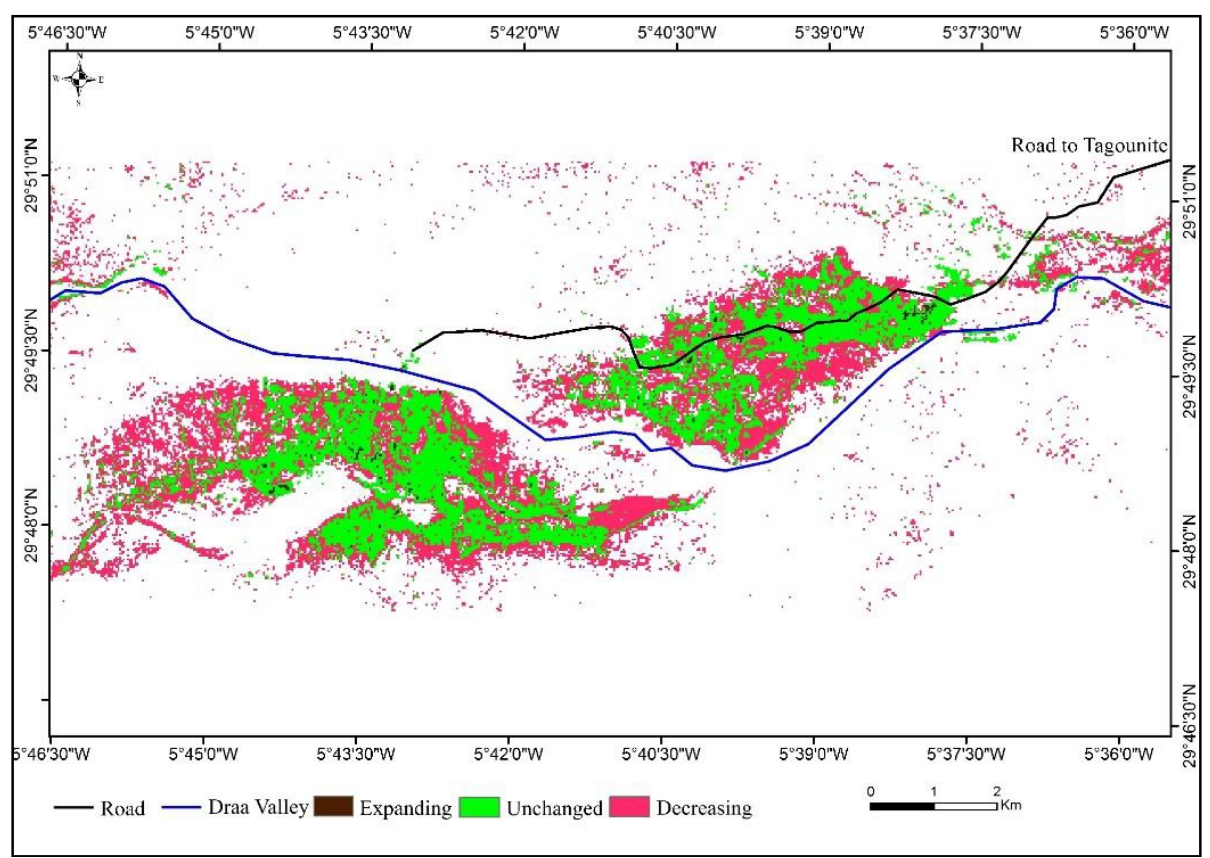

Fig. 5. The absolute spatial rate of change of the M'hamid oasis between 1984 and 2016

\section{Discussions}

To better understand the causes of the degradation of the oasis of M'hamid, we will study this phenomenon from several angles of vision, integrating the potential factors of this accelerated degradation, such as climate changes, rarity of water, tourism and migration.

\section{Climate conditions}

The M'hamid was subjected to severe climatic conditions tending towards aridity every year. Precipitation are rare (between 4 and $150 \mathrm{~mm}$ ) with a very high frequency of years below the average (15 of 26), having characteristics of a random annual distribution (Fig. 6). The annual large floods lead to erosion of the cultivated terraces along the watercourses. The climatic zone is also characterized by high temperatures especially between June and September ( 43 to $50^{\circ}$ ); Its high thermal amplitudes $\left(20^{\circ}\right.$ ); and a Very long duration of insolation (3055 to 3055 hours/year). The high evapotranspiration due to the frequency of storms and the scarcity of vegetation cover as well as the high heat that prevails throughout the year, increase the irrigation water demand. 


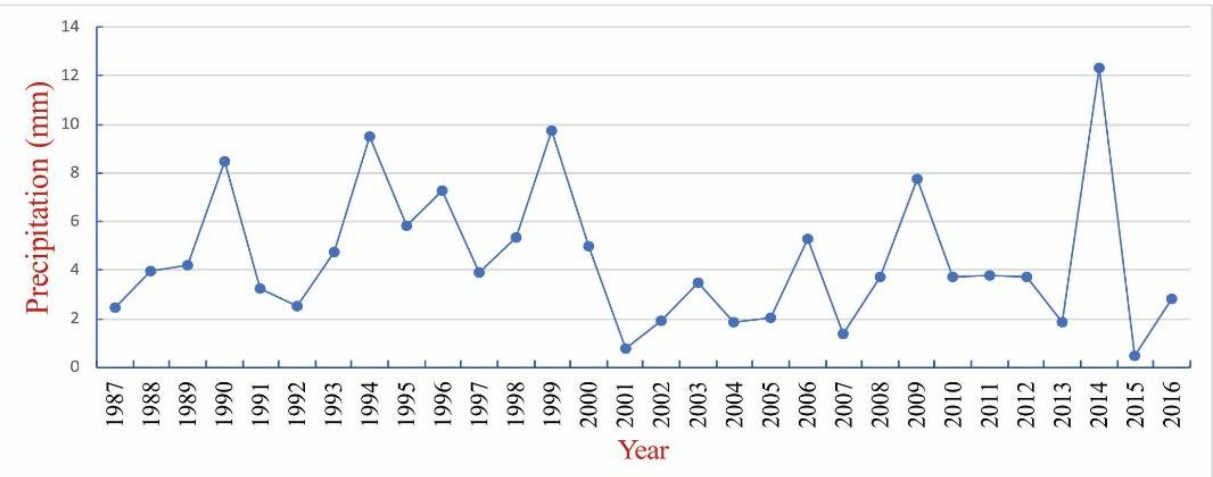

Fig. 6. The average annual precipitation between 1987-2016 (Tagounite station)

The area is largely exposed to the Saharan influences, the winds are strong, and cause the movements of the sand towards the fields and the inhabitants (Fig. 7). Two types of wind have an especially negative influence of the oasis because of their drying nature, Chergui (eastern wing) and Sirocco (southern wind) (Dłużewski \& Krzemień, 2008).

These very arid climatic conditions accelerate the sand dunes movements and desertification of M'hamid oasis.

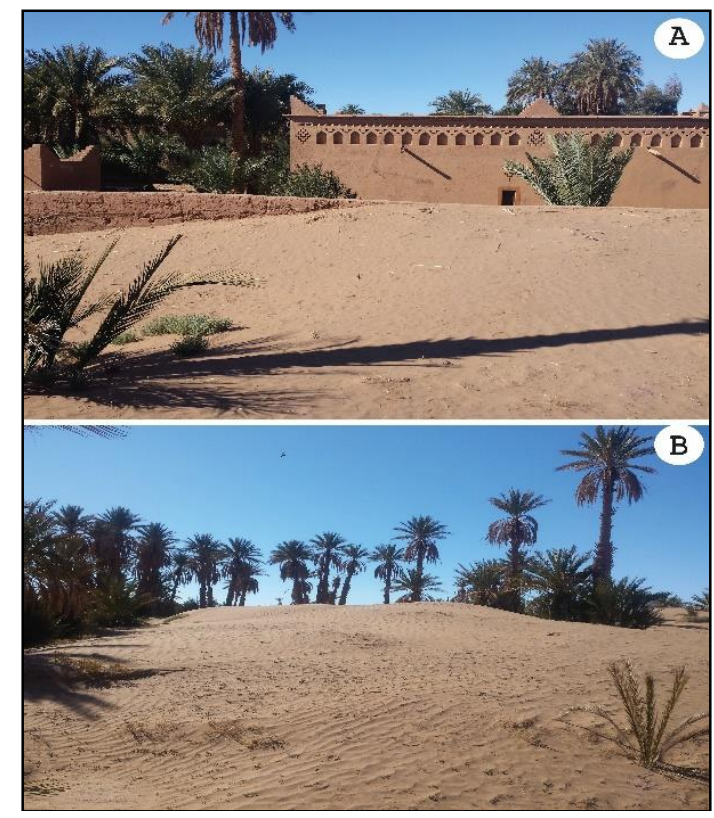

Fig. 7. Example of sand encroachment to building (A) and fields (B)

\section{Water scarcity and desertification}

In a semi-arid context, water is primordial and a crucial element of the life existence. The main characteristic of M'hamid oasis is the scarcity of water, the salinity of water and soils, more than $35 \%$ of agricultural land is affected by salinity (Karmaoui et al., 2015) and Produces a decrease in 
agricultural land. As a result, agricultural land is converted into tourist projects or sterile sandy lands.

To remedy the situation, the Government built in 1972 the Mansour Eddahbi dam. Whose objective was to control floods, regulate flow and supply of drinking water to local populations. The dam has generated perverse effects by disturbing the recharge of groundwater, stopping the natural fertilization of the soil and Lake Iriqui, once frequented by a large fauna and nomads (Aït Hamza \& El Faskaoui, 2000). This disruption of the ecological system, already fragile, has reinforced the tendency towards desertification.

\section{Migration and land degradation}

The population of the M'hamid has decreased from 8671 inhabitants in 1982 to 6781 in 2014 (Fig. 8), thus, 25,4\% of the population is lost. The sharp decline in the population is therefore linked to acute droughts to which Morocco is subjected particularly at the beginning of the seventies, and to climate conditions cited above; soil depletion, loss of vegetation cover and sand dunes movements. These rude conditions lead to the regression of the yields of the oasis cultures thus the migration towards places presenting the good conditions of life.

During our field visits, several residents confessed that the poor quality of the environment is the major reason of the migration, this confirms the results of a survey realized in 2010 by the EACH-FOR project, which shows that more than $70 \%$ of the interviewed revealed that there has been a strong relationship between climatic conditions and migration.

The correlation between the oasis area and the population gives a high correlation with a coefficient of correlation of 0.82 .

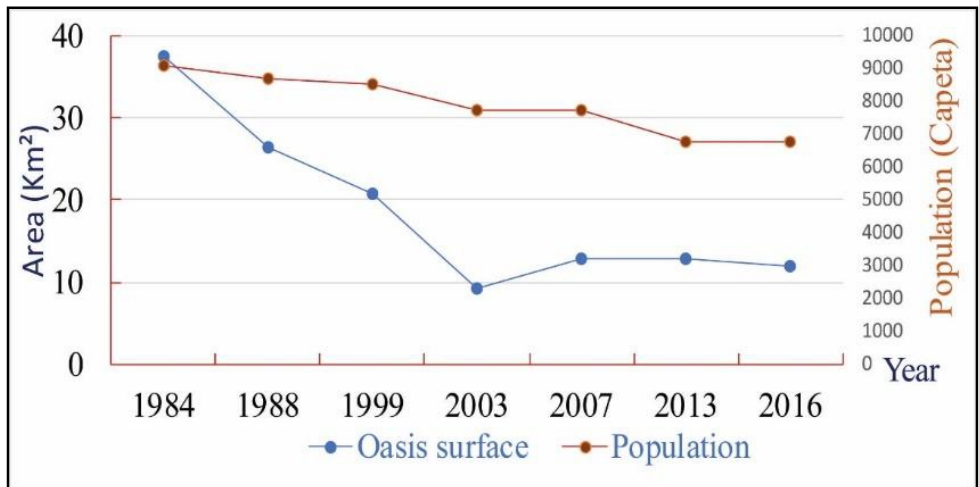

Fig. 8. The oasis area and the population of M'hmaid oasis

\section{Oasis tourism: advantage or a cause of land degradation}

For a long time, the tourism, concentrated on the coastal zones and the imperial cities of the North of Morocco, locating in the cities of 
Ouarzazate (Capital of cinema), Zagora and Arfoud its paradise (Aït Hamza\& El Faskaoui, 2010).

The rich heritage, historical relics and the beauty of nature offered by the oasis in the center of the desert in addition to the sky clarity throughout the year, the sharpness of colors and the nudity of the landscapes as well as the exceptional architecture (Ksour), sand dunes and the traditional hospitality of the populations, attract tourists, especially from abroad, which mobilizes the local economy by creating employment (Sobczak, 2008; Martin, 2006), tourism is also a consumer of water, space and a major destructor of the environment (Aït Hamza \& El Faskaoui, 2010). A tourist living at the hotel consumes three times more water per day than a resident Local (Bouaouinate, 2016).

Besides the so-called "tourist facilities": swimming pools and green lawns, there is also the pollution of water resources caused by tourism activities, especially at points of tourist concentration.

Tourism plays a key role in the development of the area, but it must be rational in preserving the sustainability of water resources and changing water-consuming practices.

\section{Conclusion}

Remote sensing Landsat images from multi-sensors, multi-date and geographical information system techniques were used to reconstructs oasis vegetation corresponding to the period 1984-2016 in the M'hamid oasis in the Middle Draa Valley. This long-term spatiotemporal change when it is analyzed. Shows not only the amplitude of the oasis dynamics, but also the degree of the impact of human activities in a context of semi-arid climate. Archival Landsat images of Landsat satellite and GIS technique have been a useful tool in this study and in long-term environmental monitoring.

This study shows that the shrinking was the most dominant change in the oasis during the last 30 years. The total area of the oasis showed an oscillating decrease between 1984-1999 compared to 1999-2013 and a sharp increase after 2003 to 2007 and a moderate decrease from 2003 to 2016, with an area 3 times smaller than the initial date.

The NDVI was used to facilitate the extraction of the vegetation as well as the models for temporal changes (SDD) which showed the rate of change for each period, demonstrate a crucial decrease over the past 30 years, reaching a value of $11.86 \mathrm{~km}^{2}$ in 2016 , present the third of the initial area of $1984\left(37.5 \mathrm{~km}^{2}\right)$. and spatial changes (Overlay analysis) whose result is a map illustrated patterns of changes in three categories Unchanged, Shrinking and Expanding, the shrinking parts are located in the boundaries of oasis. 
The M'hamid oasis degradation and desertification, are due to several factors that are principally climatic (aridity of the climate),socio-economic (tourism).

Furthermore, the construction of the Mansour Eddahbi Barrage, the irregularities of the rains and the succession of years of drought led to a modification of the oasis ecosystem. Due to these climatic conditions, the oasis population are obliged to emigration thus they leave their fields which are threatened by sand encroachments, therefore accelerating the phenomenon of sand movements, consequently desertification.

The development and rehabilitation of M'hamid requires a rationalization of tourism activities and the sensitivity of tourism actors and management of water scarcity. The use agriculture adapted to saline water. This rehabilitation will encourage the indigenous population to stay and develop their oases.

Finally, these results may be a basic data for the local administrations to develop a global strategy for the development of M'hamid.

\section{Acknowledgements}

We thank the National Center for Scientific and Technical Research for the financial support for this research (Scholarship $\mathrm{N}^{\circ}$ 1UCD2016). We thank also Prof. Gabriela - Mihaela Afrasinei, Department of Chemical and Geological Sciences, for comments that greatly improved the manuscript.

\section{References:}

1. Afrasinei G.M, Melis M.T, Buttau C, Bradd J.M, Arras C, \& Ghiglieri G. (2017a) Assessment of remote sensing based classification methods for change detection of salt-affected areas (Biskra area, Algeria). Journal of Applied Remote Sensing 11:16025. doi: 10.1117/1.JRS.11.016025.

2. Afrasinei, G.M., Melis, M.T., Buttau, C., Arras, C., Pistis, M., Zerrim, A., Guied, M., Mohamed Ouessar, M., Essifi, B., Jlali, A., Jarray, H. \& Ghiglieri, G. (2017b). Classification Methods for Detecting and Evaluating Changes in Desertification-Related Features in Arid and Semi-arid Environments. Euro-Mediterranean Journal for Environmental Integration-Springer, 21. https://doi.org/DOI 10.1007/s41207-017-0021-1.

3. Aït Hamza, M. \& El Faskaoui, B. (2010). Les oasis du Drâa au Maroc: Rupture des équilibres environnementaux et stratégies migratoires. Homme et migrations, 1284, 56-69.

4. Alagu, R., Anad, V., Senthil, K. V., Sandeep, M. \& Abhai, K. (2013). Wavelet based post classification change detection technique for 
urban growth monitoring. Journal of the Indian Society Remote Sensing, 41, 35-43.

5. Algouti, Ab., Algouti, Ah., Chbani, B., \& Zaim, M. (2001). Sedimentation and syn-sedimentary volcanism of the infra-Cambrian Adoudounian Basal series interpreted from two areas in the Moroccan Anti-Atlas Mountains. Journal of African Earth Sciences, 32, 541-556.

6. Amuti, T. \& Luo, G. (2014). Analysis of land cover change and its driving forces in a desert oasis landscape of Xinjiang, northwest China. Solid Earth, 5, 1071-1085.

7. Bannari, A., Teillet, P.M., \& Richardson, G. (1999). Nécessité de l'étalonnage radiométrique et standardisation des données de Télédétection. Journal Canadien de Télédétection, 25, 45-59.

8. Benmohammadi, A., Benmohammadi, L. Ballais, J.L., \& Riser, J. (2000). Analyse des inter-relations anthropiques et naturelles : leur impact sur la recrudescence des phénomènes d'ensablement et de désertification au sud-est du Maroc (vallée de Drâa et vallée de Ziz). Science et changements planétaires/ Séchresse, 11, 297-308.

9. Bentaleb, A. (2008). La dynamique de désertification dans le bassin du Drâa moyen : analyse et perspectives, $\mathrm{PhD}$, Thesis, Mohammed V University, Faculty of letter and human sciences, Rabat, Morocco.

10. Bouaouinate, A. (2016). La mise en tourisme des espaces oasiens du Maroc d'un tourisme de masse à un tourisme alternatif. Synthesis Report of Scientific and Pedagogical Works In order to obtain the University Accreditation, University Hasan II of Casablanca, Faculty of sciences and human Sciences, Mohmmadia, Morocco.

11. Bouazzaoui, R., Hakdaoui, M., \& Zahour, G. (2016). Monitoring the evolution of the land cover of oasis through satellite images. Case : oasis Zagora (Morocco). International Journal of Advanced Research, 4, 1918-1927.

12. Direction de la Statistique, Recensement général de la population et de l'habitat (1971): Population rurale. Région Sud, Rabat, Imprimerie Casablanca, 1973.

13. El-Hattab, M. M. (2016). Applying post classification change detection technique to monitor an Egyptian coastal zone (Abu Qir Bay). Egyptian Journal of Remote Sensing and Space Science, 19, 23-36. https://doi.org/10.1016/j.ejrs.2016.02.002.

14. Helg, U., Burkhard, M., Carith, S. \& Robert-charrue, C. (2004). Folding and inversion tectonics in the Anti-Atlas of Morocco. Tectonics, 23, 2-17. 
15. Liu, S.H. \& He, S.J. (2002). A spatial analysis model for measuring the rate of land use change. Journal of National Resources, 17,533540. Chinese.

16. Kassas, M. (1977). Arid and semi-arid lands: problems and prospects. Agro-Ecosytems, 3, 185-204.

17. Liangliang J., Guli J., Anming B. A., Hao G. \& Felix N. (2017). Vegetation dynamics and responses to climate change and human activities in Central Asia Liangliang. Science of Total Environment, 600, 967-980.

18. Liu, J., Liu, ML., Zhuang, D., Zhang, Z. \& Deng, XZ. (2003). Spatial pattern analysis of Chinese land use change. Science in China, 46, 376-384.

19. Luo, GP., Zhou, CH., Chen, X. \& Li, Y. (2008). A methodology of characterizing status and trend of land changes in oases: a case study of Sangong River watershed, Xinjiang, China. Journal of Environ Manage,88, 775-783.

20. Karmaoui, A., Ifaadassan, I., Messouli, M. \& Yacoubi-Khebiza, M. (2015). Sustainability of the Moroccan Oasean System (Case study: Middle Draa Valley). Global Journal of Technology and Optimization, 6, 2-9.

21. Maimouni, S., Bannari, A., El-Hrati, A. \& El-Ghmari, A. (2012). Potentiels et limites des indices spectraux pour caractériser la dégradation des sols en milieu semi-aride. Journal Canadien de Télédétection, 37, 285-301

22. Martin, S. (2006). Influence du tourisme sur la gestion de l'eau en zone aride Exemple de la vallée du Drâa (Maroc). License report, University of Laussane, Institute of geography. 64-134.

23. Munkhnasan L., Woo-Kyun L., Seong W. J., Jong-Yeol L., Cholho S., Dongfan P., Chul H. L, Akhmadi K. \& Itgelt N. (2017). Correlation between Desertification and Environmental Variables Using Remote Sensing Techniques in Hogno Khaan, Mongolia. Sustainability, 9, 581; doi:10.3390/su9040581.

24. NASA. (2017). Earth observing 1 (EO-1) user guide. Available at: https://eo1.usgs.gov/documents/EO1userguidev2pt320030715UC.pdf

25. Nicholas E., Ryan S. A., Stephen M. C., Anthony G. V., Rick L., Paul H. E. (2017). A survival guide to Landsat preprocessing. Ecology, 98, 920-932.

26. Ouhajou, L. (1996). Espace hydraulique et société au Maroc : Cas des systèmes d'irrigation dans la vallée du Dra, $\mathrm{PhD}$, Thesis, University of Ibn Zohr, Faculty of letter and human sciences. 
27. Rahaman, S. A., Aruchamy, S., Balasubramani, K., and Jegankumar, R. (2017). Land use/land cover changes in semi-arid mountain landscape in southern india: a geoinformatics based markov chain approach. Int. Arch. Photogramm. Remote Sens. Spatial Inf. Sci., XLII-1/W1, 231-237, https://doi.org/10.5194/isprs-archives-XLII-1W1-231-2017, 2017.

28. Robert-Charrue, C. (2006). Géologie structurale de l'Anti-Atlas oriental, Maroc, PhD, Thesis, Faculty of sciences, university of Neuchâtel, 1-49.

29. Schmidt, M., Thamm, H.P. \& Menz, G. (2003). Long term vegetation change detection in an arid environment using LANDSAT data. Geoinformation for European-wide Integration, 491-495.

30. Sobczak, K. (2008). Changes in the environment and migration in southern morocco- example of the M'hamid oasis. Miscellanea geographica, 13, 239-250.

31. Tanré, D. (1982). Interaction rayonnement-aérosols : applications à la télédétection et au calcul du bilan radiatif, $\mathrm{PhD}$, Thesis, University of sciences and techniques of Lille, Lille, France.

32. Teillet, P.M. \& Santer, R.P. (1991). Terrain elevation and sensor altitude dependence in semi-analytical atmospheric code. Canadian Journal of Remote Sensing, Vol. 17, no 1,

33. p. 36-44.

34. Tian, W.T., Xie, Y.W., \& Chen, Y.H. (2013). Spatio-temporal change of the oasis in Gaotai County in recent 50 years. Arid Zone Research. Vol.30, p.1122-1128.

35. Tucker, C. J. (1978). Red and Photographic Infrared Linear Combinations for Monitoring Vegetation. NASA Technical Memorandum, may 1978, 6-26.

36. Xie, Y., Zhao, H., \& Wang, G. (2015). Spatio-temporal changes in oases in the Heihe River Basin of China: 1963-2013. ECOSCIENCE, 22, 33-46.

37. Wang Y., Feng Q., Si J., Su Y., Chang Z. \& Xi H. (2011). The changes of vegetation cover in Ejina Oasis based on water resources redistribution in Heihe River. Environmental Earth Sciences, 64, 1965-1973.

38. XIE X., XIE H. \& Fan Y. (2016) Spatiotemporal Patterns and Drivers of Forest Change from 1985-2000 in the Beijing-TianjinHebei Region of China. Journal of Resources and Ecology. 7(4): 301-308.

39. Xie, Y.C., Gong, J., Sun, P. \& Gou, X. (2014). Oasis dynamics change and its influence on landscape pattern on Jinta oasis in arid China from 1963a to 2010a: integration of multi-source satellite 
images. International Journal of Applied Earth Observation and Geoinformation, 33, 181-191.

40. Xie, YW., Li; L.L., Zhao, X.J. \& Yuan, C.X. (2012). Spatio-temporal changes of the Heihe River Basin oasis in Northwest China over the last 25 years. In: Ghenai C. Sustainable development - education, business and management - architecture and building constructionagriculture and food security. New York: InTech, 313-330.

41. Zhang T., Wang L. \& Han Y. (2017). Evaluating the Sensitivity of Ecosystems to Soil Salinization in the Manas River Basin. 26, 917924.

42. Zhou, D., Luo, G. \& Lu, L. (2010). Processes and trends of the land use change in Aksu watershed in the central Asia from 1960 to 2008. Journal of Arid Land, 2, 157-166.

43. Zhou, D., Wang, X. \& Shi, M. (2016). Human driving forces of oasis expansion in northwestern china during the last decade-a case study of the heihe river basin. Land degradation and development, 28, 412420. 